SCIENTIFIC REPORT

\title{
Penetrating keratoplasty in children: visual and graft outcome
}

\author{
K McClellan, T Lai, J Grigg, F Billson
}

Br J Ophthalmol 2003;87:1212-1214

Aims: To review factors affecting graft survival and determinants of visual acuity after penetrating keratoplasty in children.

Methods: All cases of penetrating keratoplasty performed in an ophthalmic unit, in children aged less than 15 years at the time of operation, for the period 1984 to 2002 were included.

Results: 19 penetrating keratoplasties were done in 18 eyes of 16 children, age range 2 weeks to 14 years 8 months (mean 9.24 years), with mean follow up 6.6 years. $73.7 \%$ of grafts have remained clear for up to 14 years. Postoperative visual acuity among congenital indications for graft was better than $6 / 60$ in only $14.2 \%$ of cases, but was better than or equal to $6 / 12$ in all cases of keratoconus.

Conclusion: This series shows that prolonged corneal graft survival can be achieved in children, but successful restoration of visual acuity depends upon a period of normal visual development before the onset of corneal opacification.

$\mathrm{S}$ uccessful restoration of vision with paediatric penetrating keratoplasty has only been achieved in the past two to three decades. ${ }^{1-8}$ Previously, paediatric corneal transplantation was considered contraindicated in children, ${ }^{9}$ because of the technical challenges in paediatric anterior segment surgery created by low scleral rigidity and forward displacement of the lens-iris diaphragm..$^{31011}$ In children, the potential for post-surgical anterior segment inflammation may accelerate graft rejection. ${ }^{10}{ }^{11}$

In children early surgery is needed to eliminate corneal opacity, but low scleral rigidity increases the likelihood of significant refractive errors after corneal transplantation. The underlying disease process will also influence the timing of surgery. ${ }^{3}$ 6-8 12

While results of penetrating keratoplasty for keratoconus are favourable, ${ }^{13}$ studies have reported conflicting results of corneal transplantation for congenital corneal opacity. ${ }^{2} 351415$ We report the results of corneal transplantation and review determinants of graft clarity and vision in corneal grafts in children.

\section{METHODS}

Study subjects included all children who had corneal transplantation at age less than 15 years, by staff of the University of Sydney, Department of Ophthalmology (FAB, KMCC), between February 1984 and January 2002. Penetrating keratoplasties were performed in 18 eyes of 16 patients. Data were collected by retrospective review of the patients' medical records.

Preoperative assessment of patients included examination under anaesthesia (EUA) in the youngest children; observation with slit lamp, intraocular pressure measurement, gonioscopy, and indirect ophthalmoscopy if media were clear and electrophysiological studies and B scan ultrasonography if there was media opacity. Visual acuity was measured by Teller acuity cards in the pre-verbal child, Sheridan-Gardiner single letter matching, Kay picture cards or tumbling E charts, and Snellen chart in older children.

All corneal transplants were performed under general anaesthesia. Donor corneas were obtained from the Lions New South Wales Eye Bank. The surgical technique included use of superior and inferior rectus muscle sutures, a single Flieringa ring, and temporary silk crossover stay sutures at the limbus, $0.5-1.0 \mathrm{~mm}$ oversize graft, paracentesis, and viscoelastic. 10/0 Nylon interrupted sutures were used for all grafts, except in cases of keratoconus, which were done with a continuous suture. Topical and subconjunctival antibiotics were given at the conclusion of surgery, together with subconjunctival dexamethasone phosphate solution.

Postoperatively, initial topical therapy included dexamethasone phosphate solution and chloramphenicol four times a day for 2 weeks. Treatment with topical prednisolone phosphate solution was then continued in reducing dosage until 3 weeks after all sutures had been removed. At each postoperative visit, visual acuity was measured and slit lamp biomicroscopy performed to assess the condition of the graft. Intraocular pressure was measured by either Goldmann applanation or Schiotz tonometry. Cycloplegic refraction was used to assess all postoperative refractive errors.

Any sign of graft rejection was treated promptly with high dose topical steroids and in some cases, a short course of oral steroid. Occasionally subconjunctival or sub-Tenon's depot steroids were used to manage rejection.

\section{RESULTS}

Nineteen penetrating keratoplasties were done in 10 males and six females, age range 2 weeks to 14 years 8 months (mean 9.24 years). Follow up ranged from 2 tol4 years (mean 6.6 years). Corneal transplants were done for congenital and acquired conditions and these diagnoses and details of the patients, including co-existing ocular conditions, are summarised in Table 1.

The mean sizes of the donor cornea and the recipient bed were $7.6 \mathrm{~mm}$ (range $5.5-9.1 \mathrm{~mm}$ ) and $7.1 \mathrm{~mm}$ (range 5.0 $8.5 \mathrm{~mm}$ ) respectively. Interrupted sutures were used in 14 of the cases $(73.7 \%)$ and continuous sutures in five $(26.3 \%)$. All eyes had sutures removed before the last follow up. The mean duration for suture retention was 7.5 months (range 3-23 months).

Overall, 14 out of 19 grafts $(73.7 \%)$ have remained clear for up to 14 years. Overall graft survival for congenital conditions was $71.4 \%$ and for acquired conditions $75 \%$. Two grafts in the congenital group failed without rejection. In the acquired group, trauma to an eye grafted for keratoconus resulted in an expulsive haemorrhage, a regraft in Peters' anomaly failed without rejection and a graft for adherent leucoma failed with irreversible rejection. Overall, there were six graft 
Table 1 Congenital and acquired indications for corneal graft in children: summary of patients

\begin{tabular}{|c|c|c|c|c|c|c|c|c|c|}
\hline \multirow[b]{2}{*}{ Patient } & \multirow[b]{2}{*}{ Case } & \multirow{2}{*}{$\begin{array}{l}\text { Age at graft } \\
\text { (years) }\end{array}$} & \multirow{2}{*}{$\begin{array}{l}\text { Follow up } \\
\text { (years) }\end{array}$} & \multirow{2}{*}{$\begin{array}{l}\text { Indication for graft (congenital } \\
\text { conditions) }\end{array}$} & \multirow[b]{2}{*}{ Eye } & \multicolumn{3}{|c|}{ Visual acuity } & \multirow{2}{*}{$\begin{array}{l}\text { Co-existing ocular } \\
\text { conditions }\end{array}$} \\
\hline & & & & & & Pre-graft & Best & Last follow up & \\
\hline 3 & 4 & 1.75 & 13.0 & Peters' anomaly & $\mathrm{R}$ & $\mathrm{PL}$ & $1 / 60$ & $1 / 60$ & $\begin{array}{l}\text { Glaucoma } \\
\text { Molteno valve }\end{array}$ \\
\hline 3 & 5 & 2.8 & 12.0 & Peters' anomaly & L & PL & $1 / 60$ & $1 / 60$ & $\begin{array}{l}\text { Glaucoma } \\
\text { Molteno valve } \\
\text { Cataract }\end{array}$ \\
\hline 5 & 7 & 2.6 & 2.33 & Peters' anomaly & L & $\mathrm{PL}$ & $3 / 36$ & $\mathrm{HM}$ & $\begin{array}{l}\text { Glaucoma } \\
\text { Molteno valve }\end{array}$ \\
\hline 7 & 10 & 14.1 & 7.0 & MPS I & $\mathrm{R}$ & $6 / 36$ & $6 / 15$ & $6 / 15$ & None \\
\hline 11 & 14 & 4.4 & 0.5 & Aniridia & $\dot{L}$ & Unknown & $\mathrm{CF}$ & $\mathrm{PL}$ & $\begin{array}{l}\text { Glaucoma } \\
\text { Molteno valve } \\
\text { Cataract }\end{array}$ \\
\hline 16 & 19 & 0.04 & 2.25 & Aniridia & $L$ & Unknown & $1 / 60$ & $1 / 60$ & None \\
\hline 12 & 15 & 7.1 & 5.5 & CHED & $\mathrm{R}$ & $\begin{array}{l}\text { PL } \\
\text { Pre-Graft }\end{array}$ & $\begin{array}{l}2 / 36 \\
\text { Best }\end{array}$ & $\begin{array}{l}2 / 36 \\
\text { Last } F / U\end{array}$ & Glaucoma \\
\hline 1 & 1 & 8.5 & 10.25 & Keratoconus, acute hydrops & $\mathrm{R}$ & $\mathrm{PL}$ & $6 / 9$ & $6 / 9$ & None \\
\hline 1 & 2 & 10.9 & 7.8 & Keratoconus & $\mathrm{L}$ & $\mathrm{CF}$ & $6 / 6$ & $6 / 6$ & None \\
\hline 2 & 3 & 12.8 & 14.0 & Keratoconus & $\mathrm{L}$ & $\mathrm{CF}$ & $6 / 4$ & $6 / 4$ & None \\
\hline 6 & 9 & 14.25 & 7.5 & Keratoconus & $\mathrm{R}$ & $\mathrm{CF}$ & $6 / 7.5$ & $6 / 7.5$ & None \\
\hline 8 & 11 & 14.25 & 7.0 & Keratoconus & $\mathrm{R}$ & $\mathrm{CF}$ & $6 / 9$ & $6 / 9$ & None \\
\hline 9 & 12 & 14.7 & 7.0 & Keratoconus & $\mathrm{R}$ & $\mathrm{CF}$ & $6 / 4.5$ & $6 / 4.5$ & None \\
\hline 10 & 13 & 14.25 & 0.9 & Keratoconus & $\mathrm{R}$ & $\mathrm{HM}$ & $6 / 36$ & NPL & None \\
\hline 15 & 18 & 12.6 & 2.5 & Keratoconus & $\mathrm{R}$ & $\mathrm{CF}$ & $6 / 9$ & $6 / 9$ & None \\
\hline 4 & 6 & 3.1 & 7.0 & Neonatal corneal opacity & $\mathrm{L}$ & $\mathrm{PL}$ & $6 / 150$ & $6 / 150$ & None \\
\hline 5 & 8 & 5.0 & 5.0 & $\begin{array}{l}\text { Graft failure without } \\
\text { rejection }\end{array}$ & $\mathrm{L}$ & $1 / 60$ & $3 / 36$ & $6 / 60$ & $\begin{array}{l}\text { Glaucoma } \\
\text { Molteno valve }\end{array}$ \\
\hline 13 & 16 & 10.1 & 5.25 & Fungal keratitis & $\mathrm{R}$ & $6 / 6$ & $6 / 9$ & $6 / 9$ & None \\
\hline 14 & 17 & 13.2 & 1.0 & $\begin{array}{l}\text { Acquired adherent } \\
\text { leucoma }\end{array}$ & $\mathrm{R}$ & $\mathrm{PL}$ & $\mathrm{HM}$ & $\mathrm{HM}$ & $\begin{array}{l}\text { Glaucoma } \\
\text { Cataract }\end{array}$ \\
\hline
\end{tabular}

$\mathrm{CHED}=$ congenital hereditary endothelial dystrophy; MPSI = mucopolysaccharidosis type $\mathrm{I}$; $\mathrm{CF}=$ counting fingers at 1 metre; HM = hand movement at 1 metre; $\mathrm{PL}=$ light perception.

rejections and five out of six affected grafts are currently surviving.

Postoperative complications among the congenital indications for transplant included one case of acute uveitis resulting in a retrocorneal fibrovascular membrane (in a penetrating keratoplasty/cataract extraction with intraocular lens (IOL)), development of cataract (necessitating cataract extraction) in two patients (one with Peters' anomaly and another with CHED) and a suture related corneal abscess (Streptococcus pneumoniae) in one patient with Peters' anomaly. In the acquired indications group a patient with keratoconus had one area of peripheral anterior synechiae requiring division.

The results for postoperative visual acuity in this series of paediatric penetrating keratoplasties are shown in Table 2 . Among the group of congenital indications for graft, all corneas were opaque at birth and only $1 / 7$ (14.2\%) had a final visual acuity better than $6 / 60$, but all patients grafted for keratoconus had visual acuity better than 6/12.

Table 2 Visual acuity in penetrating keratoplasty in childhood

\begin{tabular}{llll}
\hline & $\begin{array}{l}\text { Preoperative } \\
\text { visual acuity }\end{array}$ & $\begin{array}{l}\text { Best postoperative } \\
\text { visual acuity }\end{array}$ & $\begin{array}{l}\text { Last } \\
\text { postoperative } \\
\text { visual acuity }\end{array}$ \\
\hline $6 / 12$ or better & 1 & 7 & 7 \\
$6 / 15$ to & 1 & 3 & 2 \\
$6 / 36$ & & & \\
$6 / 60$ to CF & 7 & 7 & 6 \\
HM & 1 & 1 & 1 \\
PL & 7 & 1 & 2 \\
NPL & 0 & 0 & 1 \\
Unknown & 2 & 0 & 0 \\
Total & 19 & 19 & 19 \\
\hline
\end{tabular}

\section{DISCUSSION}

The survival rate for penetrating keratoplasty in childhood has improved significantly with advances in corneal microsurgery and postoperative care. In this series relatively fewer corneal transplants were done for congenital anomalies and their survival rate was the same as that recorded by the Australian Corneal Graft Registry for the 5 year follow up of grafts in patients under the age of 20 years, keratoconus excluded. ${ }^{13}$ There have been two graft failures in this group, one transplant for Peters' anomaly and one for aniridia. The patient with Peters' anomaly had severe bilateral disease necessitating glaucoma surgery in infancy and subsequently Molteno valve implants. Only one eye has undergone corneal transplantation. Some years ago reported graft survival rates in Peters' anomaly were poor ${ }^{2}{ }^{16} 17$ but are better in recent series, ${ }^{14}{ }^{15} 18$ with graft survival around 50\%, but transplant failure may be delayed beyond 3 years. ${ }^{19} 20$ The case of aniridia had combined penetrating keratoplasty with cataract extraction and posterior chamber IOL implantation, subsequently complicated by a dense fibrovascular membrane formed around the IOL, resulting in graft failure without rejection. Other studies have found an association between graft failure and combined non-corneal procedures at the time of penetrating keratoplasty, ${ }^{3} 7813$ suggesting that such further operative procedures increase the risk of graft failure and are best avoided if possible.

The grafts performed for keratoconus were the most successful in terms of graft survival. This agrees with results published from the Australian Corneal Graft Registry, in which the 5 year survival rate for the 722 grafts performed for keratoconus was $97.5 \% .^{13}$

This series of paediatric patients, managed with corneal transplantation to improve visual acuity, has a limited number of study subjects and so cannot be used to accurately predict outcome for particular corneal conditions. It does however give prolonged follow up data for a number of congenital and acquired conditions and so provides evidence 
that corneal transplants can survive long term. Only one graft has been lost to irreversible rejection in this series. This indicates the dedicated parental involvement and availability of ophthalmic care that is essential in the early recognition of graft rejection and maintenance of paediatric corneal transplants.

Visual outcome after corneal transplantation is significantly worse in patients with congenitally determined corneal opacity. Only one of the seven cases of congenital conditions grafted had a visual acuity better than 6/60 at the time of the last follow up. This patient has mucopolysaccharidosis and although the cornea was cloudy at birth, the corneal opacity increases with age. ${ }^{21}$ Visual acuity before graft was 6/36, which was considerably better than the other patients with congenital lesions where vision ranged from PL to HM. Amblyopia associated with congenital corneal opacity is an important determinant of the final vision in these cases. ${ }^{12}$ For all patients visual acuity following penetrating keratoplasty was better than or equal to pre-graft visual acuity, enabling patients to develop ambulatory vision in the presence of amblyopia. ${ }^{22}$

Our series shows that prolonged corneal graft survival can be achieved in childhood, among patients grafted for either congenital or acquired causes of corneal opacity. Visual acuity outcomes after transplantation are, however, significantly better in patients grafted for corneal opacity or distortion acquired after infancy.

\section{Authors' affiliations \\ K McClellan, T Lai, J Grigg, F Billson, Department of Clinical}

Ophthalmology and Save Sight Institute, University of Sydney, Sydney NSW 2001, Australia

Correspondence to: Dr K McClellan, Department of Clinical Ophthalmology and Save Sight Institute, University of Sydney, GPO Box 4337, Sydney NSW 2001, Australia; kathy@eye.usyd.edu.au

Accepted for publication 26 January 2003

\section{REFERENCES}

1 Picetti B, Fine M. Keratoplasty in children. Am J Ophthalmol 1966;61:782-9.

2 Waring GO III, Laibson PR. Keratoplasty in infants and children. Trans Am Acad Ophthalmol Otolaryngol 1977;83:283-96.

3 Stulting RD, Sumers KD, Cavanagh HD, et al. Penetrating keratoplasty in children. Ophthalmology 1984;91:1222-30.

4 Panda A, Mohan M, Venkateswarlu K, et al. Keratoplasty in children. Ann Ophthalmol 1988;20:183-7.

5 Cowden JW. Penetrating keratoplasty in infants and children. Ophthalmology 1990;97:324-9.

6 Erlich CM, Rootman DS, Morin JD. Corneal transplantation in infants, children and young adults: experience of the Toronto Hospital for Sick Children, 197988. Can J Ophthalmol 1991;26:206-10.

7 Dana M, Moyes AL, Gomes JAP, et al. The indications for and outcome in paediatric keratoplasty: a multicenter study. Ophthalmology 1995;102:1129-38.

8 Gloor P. Pediatric penetrating keratoplasty. In: Krachmer JH, Mannis MJ, Holland EJ, eds. Cornea: surgery of the cornea and conjunctiva. St Louis: Mosby Year Book, 1997:1731-56.

9 Leigh AG. Corneal grafting. Br J Clin Pract 1958;12:329.

10 Ariyasu RG, Silverman J, Irvine JA. Penetrating keratoplasty in infants with congenital glaucoma. Cornea 1994;13:521-6.

11 Sajiadi H, Javadi MA, Hemmati R, et al. Results of penetrating keratoplasty in CHED. Cornea 1995;14:18-25.

12 Edward DP, Li J, Sawaguchi S, et al. Diffuse corneal clouding in siblings with foetal alcohol syndrome. Am J Ophthalmol 1993;115:484-93.

13 The Australian Corneal Graft Registry. Report of Australian Corneal Graft Registry. Aust NZ J Ophthalmol 1993; Suppl: 1-48.

14 Parmley VC, Stonecipher KG, Rowsey JJ. Peters' anomaly: a review of 26 penetrating keratoplasties in infants. Ophthalmic Surg 1993;24:31-5.

15 Cameron JA. Good visual result following early penetrating keratoplasty for Peters' anomaly. J Pediatr Ophthalmol Strabismus 1993;30:109-12.

16 Kampik A, Lund OE, Halbig W. Perforierende keratoplastik bei kongenitalen Hornhauttrubungen. Klin Monatsbl Augenheilkd 1986;188:188-92.

17 Gollamudi SR, Traboulsi El, Chamon W, et al. Visual outcome after surgery for Peters' anomaly. Ophthalmic Genet 1994;15:31-5.

18 Brown SI, Salmon SM. Wound healing of grafts in congenitally opaque infant corneas. Am J Ophthalmol 1983;95:641-4.

19 Dana MR, Schaumberg DA, Moyes AL, et al. Corneal transplantation in children with Peters' anomaly and mesenchymal dysgenesis. Ophthalmology 1997; 104:1580-6.

20 Yang LLH, Lambert SR, Lynn MJ, et al. Long-term results of corneal graft survival in infants and children with Peters' anomaly. Ophthalmology 1999;106:833-48.

21 Muenzer H. Mucopolysaccharidoses. Adv Pediatr 1986;33:269-302.

22 Frucht-Pery J, Chayet AS, Feldman ST, et al. The effect of corneal graffing on vision in bilateral amblyopia. Acta Ophthalmol 1989;67(S192):20-3. 